\title{
TO THE ISSUE OF VOCATIONAL ENGLISH SYLLABUS DESIGN FOR SUSTAINABLE FOREIGN LANGUAGE EDUCATION
}

\section{Movchan L.G., PhD in Pedagogics (Vinnytsia)}

The article considers English language syllabus design for non-linguistic faculties on the basis of positive experience of some European countries. Current vocational foreign language education is determined by the global context of education and employment on the whole: labour force mobility, life-long learning and sustainable social and economic development. Communicative competence in a foreign language has become a prerequisite of sustainable education nowadays. In order to establish effective foreign language education, Ukraine must bring the quality of its education to the European standards, taking into account positive foreign experience. Analyzing English language teaching at nonlinguistic universities of our country, we see the problems related to the curriculum and syllabus design. The absence of integration of foreign language teaching at secondary school and the requirements to the communicative competence in English of non-linguistic students fail to provide the sufficient level of foreign language education in the country and as a result, the quality of higher education. The discrepancy between the low initial level of proficiency in English of first-year students alongside with the syllabus designed for mastering this foreign language for specific purposes is a problem, hard to cope with both for teachers and students. Windows User decision alongside with gradation of coursesWindows User according to their level, so that the students can attain the necessary communicative skills to be able to learn English for professional purposes, read specialized literature sources, participate in discussions and make presentations or communicate business ideas in a written form. The analysis of the syllabi of some European universities shows differential approach in teaching FL, taking into account the students' needs so that they actively and effectively participate in the study process and show sufficient performance.

Key words: curriculum, sustainable foreign language education, syllabus, vocational English.

Мовчан Л.Г. Щодо питання конструювання програм 3 англійської мови за професійним спрямуванням для безперервної іншомовної освіти. У статті розглядаються питання конструювання програм з англійської мови для професійного спілкування 3 урахуванням позитивного зарубіжного досвіду. Сучасне навчання професійної іноземної мови визначається глобальним контекстом освіти та зайнятості в цілому: мобільністю робочої сили, навчанням упродовж усього життя та сталим соціальним та економічним розвитком. Комунікативна компетентність іноземної мови стала передумовою сталого навчання також в Україні та визначає необхідність наближення якості іiї іншомовної освіти до європейських стандартів. Аналіз викладання англійської мови в нелінгвістичних університетах нашої країни вказує на проблеми, пов'язані 3 розробкою навчального плану i програм. У багатьох університетах Європи курс англійської мови вивчається поступенево залежно від початкового рівня володіння нею, а володіння іноземною мовою на рівні В2 $\epsilon$ необхідною умовою вступу на основний курс навчання в немовних ЗВО. Достатне

(C) Movchan L., 2019 
навчальне навантаження для виправлення ситуації було б найкращим рішенням поряд із градацією курсів відповідно до їхнього рівня, щоб студенти могли отримати необхідні комунікативні вміння для вивчення англійської мови для професійних цілей, читати спеціалізовані літературні джерела, брати участь у дискусіях, проводити презентації або повідомляти бізнес-ідеї в письмовій формі. Відтак, немовним 3ВО України варто адаптувати навчальні плани відповідно до потреб студентів та їх початкового рівня володіння іноземною мовою, удосконалити зміст і форми самостійної роботи студентів і іiі контролю, застосувати диференційований підхід 3 урахуванням потреб студентів.

Ключові слова: англійська мова за професійним спрямуванням, безперервна іншомовна освіта, навчальний план, програма.

Мовчан Л.Г. К вопросу о конструировании программ по профессиональному английскому языку для непрерывного иноязычного образования. В статье рассматриваются вопросы конструирования программ по английскому языку для профессионального общения с учетом положительного зарубежного опыта. Современное профессиональное обучение иностранному языку определяется глобальным контекстом образования и занятости в целом: мобильностью рабочей силы, обучением в течение всей жизни и устойчивым социальным и экономическим развитием. Коммуникативная компетентность в иностранном языке стала предпосылкой непрерывного обучения также для Украины и определяет необходимость ориентации на европейские стандарты. Анализ преподавания английского языка в нелингвистических университетах нашей страны указывает на проблемы, связанные с разработкой учебных планов и программ. Во многих университетах Европы курс английского языка изучается ступенчато исходя из начального уровня владения им, достижение уровня В2 является необходимым условием поступления на основной курс обучения в неязыковых вузах. Достаточная учебная нагрузка для исправления ситуации была бы лучшим решением вместе с градацией курсов в соответствии с начальным уровнем студентов, чтобы они могли получить необходимые коммуникативные умения для изучения английского языка для профессиональных целей, читать специализированные литературные источники, участвовать в дискуссиях, проводить презентации или излагать бизнес-идеи в письменной форме. Поэтому неязыковым вузам Украины следует адаптировать учебные планы в соответствии с потребностями студентов и их начальным уровнем владения иностранным языком, усовершенствовать содержание и формы самостоятельной работы студентов и ее контроля, применить дифференцированный подход.

Ключевые слова: английский язык для профессионального применения, непрерывное иноязычное образование, программа, учебный план.

The topicality of the research. Nowadays learning foreign languages stands in the centre of scientific research in pedagogy and methodology of higher education since the need for foreign language skills is growing and education is acquiring a globalized content. Labour force mobility requires that specialists can work in almost any country in the world and the changing labour market with some professions vanishing and others emerging calls for life-long learning. 
Learning for sustainability is the modern trend in educational system which implies constant changes on the labour market and acquisition of new skills.

Foreign language learning (FLL) has now exceeded the margins of learning the subject as it is, but for specific professional purposes and the result of it is communicative competence in a foreign language which is regarded as the ability to solve communicative tasks with native speakers taking into account norms and cultural traditions in the conditions of direct and mediated communication. O. Savchenko considers foreign language communicative competence as a resultaction feature of the education and the prerequisite of its sustainability [9: 4]. Thus, being the prerequisite of sequent education, this sphere lies at the basis of curriculum design for higher education and serves as its qualitative characteristic.

European experience of designing curricula and syllabi for foreign languages at economic universities is of certain relevance for our scientific research, because it is embraced by the European documents on language policy, language learning and life-long learning.

This defined the aim of the research: finding out the principles of curriculum design with respect of foreign languages' teaching at higher educational establishments of Europe.

The degree of scientific research of the issue. The theme of curriculum design is not new in pedagogy and there are copious works considering different approaches of curriculum and syllabi design at various stages of education (I. Bim, N. Borisko, V. Hamanyuk, S. Amelina, J. van Ek, D. Nunan, R. White, D. Wilkins and others). N. Borisko (2006) considered new syllabi for foreign languages for higher education institutions. H. Krumm (2000) considered the curriculum design under the impact of globalization. R. White (1989), D. Wilkins (1976) devoted his research to the curriculum design for English. K. Livingstone (2015) studied curriculum design for foreign languages for higher educational institutions in Portugal. J. Airey studied the implementation of bilingual education in Sweden.

However, this issue has not received enough attention in the Ukrainian scientific literature. Taking into consideration Ukraine's integration into the European community, there is need for deeper research into the curriculum design, learning foreign experience in this field and integrating it into Ukrainian curricula. 
Therefore, our particular interest defines the aim of the research - to find out the principles of curriculum design in regard with foreign languages in some European countries for different reasons:

1) the education pattern is constantly changing due to new technologies, global changes, mobility etc.;

2) the qualitative feature of education embraces new and new competencies;

3) within the European Union the principle of labour force mobility is working and the need for new skills is growing.

Presentation of the main material. Ukraine has already made significant changes in higher education for the past decades. The most relevant is introduction of obligatory GSE for all applicants to the university which gave all pupils a transparent access to higher education and even improved the quality of higher education at the initial stage. Another step was abolishing standard syllabi for foreign languages which retained the features of the Soviet approach to foreign language learning irrespective of the specific professional purposes.

First of all, we would like to tackle the notion of a curriculum, which is so diverse in different languages, that is even different to compare according to certain parameters such as goals, functions and the place of the subjects. The word "curriculum" comes from Latin defining “currere” (course), meaning purposeful process. A. Prevedel (2003) says that curriculum is an outline of a didactic process [15: 8].

Thus, the concept of curriculum implies a syllabus, guidelines (Richtlinien), Lehrplan, Laeroplan, Rahmencurriculum, curriculum etc.

For instance, in Germany they differentiate between the Lehrplan (study plan) and the Curriculum, where the first describes general educational goals and the content of education and the second (Curriculum) defines the goals for each stage of education alongside with prŭcised content, giving the guidelines concerning the teaching methods and approaches. While the Lehrplan is issued by the Ministries of education (separate for each land in Germany) and serves as a framework for further development, the Curriculum resembles a syllabus for each subject and is more detailed, containing the forms and methods of teaching. According to N. Borisko, the main difference between them are the goals of their development and their obligation extent for educational institutions [1: 4].

In many English-speaking countries curriculum deals with the content of education defining the subjects to study (compulsory and 
elective) and goals to attain in each subject. Syllabus deals with a separate subject and is more detailed concerning the methods, goals and forms of teaching at different levels and stages.

Ukraine made a step from the standard curriculum, the anachronism of the Soviet education system towards a framework curriculum and framework syllabus for foreign languages. Framework syllabi are more flexible being more generalized and contain study goals that meet the society needs.

In Swedish pedagogy the concept of curriculum was first introduced in 1886, when Scandinavian teachers and methodologists in pursuit of making changes in teaching languages, established The Scandinavian associacion of reforming language teaching «Quousque tandem» under the motto of O. Yespersen's pamphlet Der Sprachunterricht muss umkehren (Language learning must change) [5: 277]. The members of this "Quousque tandem” proposed that language learning and teaching should be based on spoken language, while study materials must contain logical sentences that make sense, rather than artificial speech abstracts [5: 280].

$\mathrm{N}$. Borisko classifies syllabi according to their content (content syllabi), skills (skill-based), methods (method-based) syllabi which in their turn are subdivided into process syllabi and procedural syllabi [1: 4-5]. Content-based or product-oriented syllabi for foreign languages are based on socio-pragmatic linguistics approach and comprise the material or topics and situations to learn. They are more typical for the 1970s-1990s. In our opinion, modern foreign language learning at higher educational establishments in Ukraine is based on a skill-based syllabus, as the main goal of training is acquisition of certain communicative skills including strategic, intercultural and professional. In this respect, suffice it to mention that a communicative skill can be formed only through repeated listening and following the patterns, then trying to reproduce them through trials and mistakes. "Studies have shown that when knowledge is learned passively, without skills, it is often only learned at a superficial level (the knowledge may be "troublesome": ritual, inert, conceptually complex, foreign or tacit), and therefore, not readily transferred to new environments" [11: 2].

According to the survey conducted by the Project team Education First for English Proficiency Index, Ukraine is among the countries with the moderate proficiency in English ranking 43 (52,86 \% of the 
total population) among 44 surveyed countries. The leading positions belong to Sweden (70,72\%) and Netherlands (70,31\%) [14].

The explanation to Swedish success in foreign language learning lies in its language policy and curriculum design. First, suffice it to mention that Sweden's language policy is multinational and is based on 3 principles that meet the interests of all national groups represented in the population of the country. According to the language policy of Sweden:

1) Swedish is the official language of the country, which is compulsory for education and career purposes.

2) English is a compulsory main foreign language to be taught at all levels of education.

3) National minorities have the right to obtain their education in their native language [5: 52].

Second, interrelation of the language and educational policy of Sweden is reflected in numerous documents of the Council of Europe in the field of foreign language training which are now the basis for developing and reforming national educational systems. They defined the ways of establishing Sweden's educational policy: 1) knowledge of over 2 foreign languages to promote and provide labour force mobility; 2) early-age and life-long foreign language learning for sustainable development; 3) creating a favourable language learning medium; 4) immersion of foreign language learning with non-language subjects;

5) communicative and sociocultural content of foreign language learning [5].

The curriculum design for foreign languages in Sweden testifies to the sustainability of foreign language learning at all stages of education. The multistage level of FLT in Sweden is defined in the Laeroplan for the compulsory school and gymnasie skola (secondary school) which are designed on the principles of the CEFR Common European Framework of References and the European Language Portfolio according to the following pedagogical and methodological conditions:

- inclusion and accordance of all levels of language command: basic, threshold and advanced;

- development of communicative, intercultural and strategic competencies;

- taking into account and implementing positive foreign experience of FLT into the national system, forming national strategies and guidelines; 
- development of student's autonomy in learning [5].

Comparing the standard syllabus for upper-school of Ukraine realizes the content of education depending on the chosen study profile, according to which English is taught at the following levels:

- standard level provides general educational level corresponding to the level B1 of CEFR;

- academic level is meant for humanitarian and philological schools and corresponds to level B1+ according to the CEFR;

- the specific level implies in depth FLL and corresponds to level B2 of the CEFR see the table [5: 11-12].

Comparison of levels of English command in the systems of school education in Ukraine and Sweden [5: 136]

\begin{tabular}{|c|c|c|c|c|}
\hline $\begin{array}{c}\text { Secondary } \\
\text { educational } \\
\text { establishment } \\
\text { s of Ukraine }\end{array}$ & $\begin{array}{l}\text { Levels } \\
\text { accordin } \\
\text { g to } \\
\text { CEFR }\end{array}$ & $\begin{array}{l}\text { Compulsory and } \\
\text { gymnasia schools } \\
\text { (upper school) }\end{array}$ & $\begin{array}{l}\text { Levels } \\
\text { according to } \\
\text { the Swedish } \\
\text { system }\end{array}$ & CEFR \\
\hline $\begin{array}{l}\text { Primary } \\
\text { school 2-4 } \\
\text { forms }\end{array}$ & A1 & $\begin{array}{l}\text { Primary school } \\
\text { within compulsory } \\
\text { school } \\
\text { (1-3 forms) }\end{array}$ & Stage 1 & $\begin{array}{l}\text { A1- } \\
\text { A2 }\end{array}$ \\
\hline \multirow[t]{2}{*}{$\begin{array}{l}\text { Compulsory } \\
\text { school } \\
\text { 5-9 forms }\end{array}$} & \multirow[t]{2}{*}{$\mathrm{A} 2+$} & $\begin{array}{c}\text { Compulsory } \\
\text { school } \\
\text { (obligatoriska } \\
\text { skola) (4-5 forms) }\end{array}$ & Stage 2 & A2 \\
\hline & & $\begin{array}{c}\text { Compulsory } \\
\text { school } \\
\text { (obligatoriska } \\
\text { skola) (6-7 forms) }\end{array}$ & Stage 3 & $\begin{array}{l}\text { A2- } \\
\text { B1 }\end{array}$ \\
\hline
\end{tabular}




\begin{tabular}{|c|c|c|c|c|c|c|}
\hline & & \multicolumn{3}{|c|}{$\begin{array}{c}\text { Compulsory } \\
\text { school } \\
\text { (obligatoriska } \\
\text { skola) (8-9 forms) }\end{array}$} & Stage 4 & B1 \\
\hline \multirow{3}{*}{ 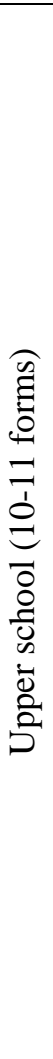 } & $\begin{array}{c}\text { Standard } \\
\text { level }\end{array}$ & B1 & \multirow{3}{*}{\multicolumn{2}{|c|}{ 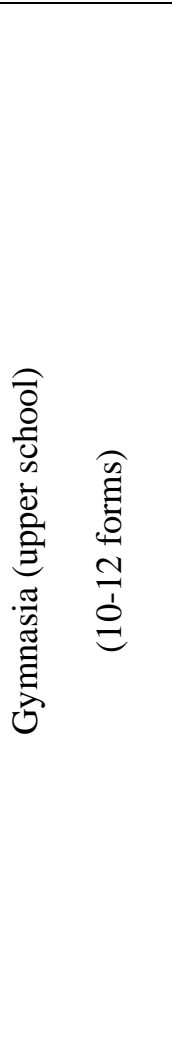 }} & $\begin{array}{c}\text { Stage } 5 \\
\text { (course «A»- } \\
\text { compulsory for } \\
\text { all gymnasia } \\
\text { programs) }\end{array}$ & B1-B2 \\
\hline & $\begin{array}{l}\text { Academi } \\
\text { c level } \\
\text { (humanit } \\
\text { arian) }\end{array}$ & $\mathrm{B} 1+$ & & & $\begin{array}{c}\text { Stage 6 } \\
\text { (course «B» for } \\
\text { programs } \\
\text { «Social } \\
\text { sciences», } \\
\text { «Natural } \\
\text { sciences», } \\
\text { «Arts», } \\
\text { «Technical } \\
\text { science») }\end{array}$ & B2 \\
\hline & $\begin{array}{c}\text { Profile } \\
\text { level }\end{array}$ & B2 & & & $\begin{array}{c}\text { Stage } 7 \\
\text { (Elective } \\
\text { course «C»- } \\
\text { profile level) }\end{array}$ & $\mathrm{B} 2-\mathrm{C} 1$ \\
\hline
\end{tabular}

However, in comparison with the Swedish students Ukrainian students lag behind as for their command of English. First of all, some scientists (O. Pasichnyk) note certain incoherence in teaching foreign languages at schools, higher non-linguistic educational establishments and the demands for their enrollment for the master program [7]. For a long time, a General Assessment Test in English has not been a 
necessary requirement to enter non-linguistic faculties. So, being aware of this, future students seldom prepared themselves for this examination and improved their language skills. Second, the amount of an academic load for the subject "Foreign language" at non-linguistic faculties (except Informational Technologies, Media) is insufficient and even decreased during the last decade (from 3 years of study to 2) with a 2 hours' weak load (by order of the Ministry of Education and Science of Ukraine № 642 dated July 09, 2009). Suffice it to mention, that this resolution was adopted during globalization of education, bringing the Ukrainian education in accordance with the European standards, language policy and language education policy of the Council of Europe aimed at promoting language learning. Second, after 2 years of non-dealing with this subject students have to take a General Assessment Test in foreign language at the advanced level that corresponds to B2 according to CEFR, although most of them can only read and translate texts including professional or general lexis with a dictionary. Moreover, most of students cannot provide successful written communication lacking vocabulary and necessary grammar skills.

This inconsistency in requirements and educational provisions leads to the students lacking this important skill. However, the global labour market which is highly determined by labour force mobility sets much higher requirements to future specialists than even a decade or two ago. Nowadays the students must be able not only to read professional texts and compile business documents, they must be able to communicate professional ideas, participate in negotiations, understand the meaning of new notions and the context in which they are used. Presentations being a necessary attribute of any business event are mostly held in English.

As we have mentioned above, the shrunk academic load for the subject resulted in so called compression of the study material. For instance, the average generally accepted working load for the subject "Foreign language” is about 270 hours for 2 years of study. However, to reach the proficiency in a FL at level B2 necessary to enter the master program, one needs at least 648 hours, which is three times as large as the actual working load. Besides, only 120 hours of 270 are meant for practical lessons. In this respect we agree with O. Pasichnyk, who claims that students have no time for revising the material and doing the assignments which on the whole demotivates and discourages 
them [7]. As we know, one of the most important stages of material acquisition is its consolidation which can be compared with revision and can take place either at the end of the lesson or after it. As a result, teachers have not enough time to check the students' performance and help them improve it. Therefore, students often feel discontented with their performance and cannot go ahead in their studies having no steady basis of necessary knowledge.

Despite having autonomy in tailoring their curricula, higher educational establishments of Ukraine fail to bring FLT in conformity with the requirements set by the CEFR, although standard syllabi for foreign languages for higher educational institutions were designed with account of this important document on language education, teaching and assessment. To them refer: "National ESP Curriculum for Universities" and "Rahmencurriculum fuer studienbegleitenden Deutschunterricht an ukrainischen Hochschulen und Universitäten". The latter is based on the principles of plurilingualism and multilingualism, professional, intercultural and communicative orientation, autonomous learning. As a result, students should develop the skills of both spoken and professional German, participating in discussions, giving arguments, making presentations, using communicative means of professional interaction [8: 13]. This syllabus proposes professional topics to learn corresponding different professional directions and the necessary competencies to achieve. It also gives a detailed descriptions of all forms and methods of teaching and learning, as well as student-student, student-teacher interaction. Significant attention is paid to student's autonomy in the learning process. The language portfolio helps the students and teachers in assessment. The Rahmencurriculum is very adaptable to various conditions, however the requirements to the students' communicative competence in German are high which calls for creating necessary pedagogical conditions to enable both parties: teachers and students to achieve the set goals. In our opinion, this considerably big volume of work requires a large amount of time, so that the students can develop communicative and general skills. The Rahmencurriculum stresses, that all these "skills and competencies must be developed in a long-term period, systematically and in didactically structured form. These multidimensional abilities (alongside with cognitive, social, motivational and self-managed aspects) will enable the person to successfully perform various complex interactions in life" [8]. Thus, the implication of this 
Rahmencurriculum is a long-term learning process aimed at achieving various study goals and acquisition of a set of communicative skills in a professional sphere.

Despite the recommendation letter of the Ministry of Education and Science of Ukraine "On organization of studying humanities" № 1/9120 dated March 11, 2015 [4] that calls all the universities to create necessary conditions for learning English as the language of international academic communication in which the students should achieve level B2 according to the CEFR [2], little has been done towards increasing the academic load and designing a curriculum that is based on real students' needs.

For instance, curriculum for the Bachelor Program "Enterprise economics" at the University of Vienna offers the course of "Business English" which consists of two parts. Part 1 of UE Business English I comprises 3 ECTS, 2 SSt and Part II UE Business English II, 3 ECTS, 2 SSt. Enrollment for the program is performed on the basis of certificate of English B2 according to the CEFR, which can be obtained on passing Oxford Online Placement Test. In fact, this requirement is quite well justified, because the goals of learning Business English include: developing the reading skills competency to read texts containing professional vocabulary in the spheres of management, corporate management, joint ventures and take overs, banking, valuables, international trade, accounting and economic policy; speaking skills through discussions and presentations; writing skills (business papers, presentations etc.) [13]. Positive performance in UE Business English I is the precondition of enrollment to UE Business English II. For students who have not achieved level B2 in English, there is a preparatory course for 4 ECTS during the $1^{\text {st }}$ term, while Business English (Part I and Part II) is studied during the $2^{\text {nd }}-4^{\text {th }}$ terms.

In fact, the study period corresponds with the span of time Ukrainian students study English at the non-linguistic university. However, as the analysis shows, there is a remarkable difference in the academic load. The average load for classroom lessons in most European universities ranges within 240-280 hours. According to A. Turchin's analysis 240270 hours [10] in comparison with 120 hours in Ukraine.

Here, suffice it to mention that despite a large amount of the academic load for the independent work in the Ukrainian curricula, 
there is remarkable discrepancy between the theory and practice. In fact, students for various reasons do not effectively utilize this time:

- lack of effective control, for instance tutorships, where students can demonstrate their progress and receive the guidelines on further steps;

- little attention is paid to the forms and methods of student's independent work, tasks are mostly formal and not elaborated enough;

- low level of initial communicative competence in a foreign language is a demotivating factor that discourages the students from autonomous learning, for they often feel unable to cope with the tasks by themselves, while a language studying process is effortand time consuming.

Again, suffice it to say, that in most European education systems the emphasize is put on the FLT at the stage of compulsory and secondary schooling, where children achieve a necessary level of communicative competence and can apply these skills in learning professional foreign language.

Analyzing the syllabus of English LIU 43103 (2018) for the first cycle for exchange students in Chemistry, Biology and Biotechnology, as well as for economics at Linkoeping University (Sweden) which lasts 1,3 year (30 ETCS credits) of preliminary scheduled hours make up $30 \mathrm{~h}$ and recommended self-study hours - $77 \mathrm{~h}$. Entry requirements are 5 years of English at pre-university level, besides, there are threshold requirements for progression within the programme [12].

The course is meant for exchange students to make sure they reach the level of communicative competence in English, which the Swedish applicants have already acquired and fit in the study context. The course sets the aim to develop the ability of exchange students "to communicate successfully in English with an emphasis on the spoken word. Through listening activities, discussions and a systematic revision of basic grammar, the student will acquire the confidence and skills necessary to participate fully in University life and studies in Linkoeping. After the course, the student shall be able to:

- understand the major points in a lecture or discussion in English;

- extract and summarize the most important elements of a lecture or discussion;

- actively participate in group discussions;

- select an appropriate register for the communicative activity at hand; 
- structure and present information in an appropriate manner;

- develop an argument or opinion;

- critically evaluate their own spoken language and be able to take remedial action.

Moreover, the predominant forms of lessons are discussions, presentations, so spoken communication and attendance is compulsory.

Thus, as we see from the Swedish example, of the sequent foreign language learning is an important precondition of modern professional training, which is necessary to establish in Ukraine.

Alongside with these educational factors, a social factor hinders the development of foreign language competency of our students. As compared to Sweden, Ukraine has little exposure to English speaking media in the societal life. Sweden solves this problem in such a way:

- by remarkable presence of English in all social domains of the country, thus greater exposure of the Swedes to this language and its far better acquisition;

- widely spread practice of content and language integrated learning, i.e. teaching other than language subjects by means of English or other FL;

- compulsory testing of English language skills according to levels A, $\mathrm{B}$ and $\mathrm{C}$ (depending on the chosen upper school courses) as a precondition for university enrolment, which on the whole serves as a motivating factor of studying FL.

Although Ukraine has made important steps in this direction, as our research shows, a lot must be done to improve the situation in rural areas to provide necessary conditions for teachers's professional development, provide schools with necessary IT and make the study process more effective.

Conclusions. Teaching foreign languages for professional purposes can not stand alone in the whole process of foreign language teaching starting from an early age. Educational for sustainable development means available cohesion and consistency in acquisition communicative skills at different stages of education. The discrepancy between the requirements to foreign language proficiency in the university syllabi and the initial level of foreign language proficiency of the school alumni calls for measures related the syllabi and curricula design that would rectify this situation through staging the process of English teaching at non-linguistic faculties, apply differential approach 
in teaching, adjust the syllabus to students' needs, increasing the academic load for foreign languages.

Perspectives of future research. The obtained results call for further theoretic and practical research into organizational and pedagogic conditions of maintaining sustainable foreign language education, extracurricular activities in improving mastering foreign languages and the content of foreign language learning at further stages of education.

\section{LITERATURE}

1. Бориско Н.Ф. Новые типовые программы по иностранным языкам и их особенности. Іноземні мови, 2006. № 3. С. 3-9.

2. Загальноєвропейські Рекомендації 3 мовної освіти: вивчення, викладання, оцінювання. Наук. ред. укр. видання д. пед. н., проф. С.Ю. Ніколаєва. К.: Ленвіт, 2003. 273 с.

3. Исмаилов Э.Э. Шведская модель довузовской профессиональной подготовки: монография. Карлскруна: муниципальная гимназия им. Чэпмена, 2002. $342 \mathrm{c}$.

4. Лист Міністерства освіти і науки України «Про організацію вивчення гуманітарних дисциплін» № 1/9-120 від 11.03. 2015 p. URL: http://osvita.ua/legislation/Vishya_osvita /46343/ (дата звернення: 17.02.2019).

5. Мовчан Л.Г. Розвиток змісту шкільної іншомовної освіти в Королівстві Швеція: дис. канд. пед. наук: 13.00.01/ Відкритий університет розвитку людини «Україна». Київ, 2012. 224 с.

6. Наказ МОН України «Про організацію вивчення гуманітарних дисциплін за вільним вибором студента» № 642 від 09.07.2009 p. URL: http://old.mon.gov.ua/ua/about-ministry/normative/147 (дата звернення: 22.02.2019).

7. Пасічник О.С. Пасічник О.О. Оптимізація процесу іншомовної підготовки студентів немовних спеціальностей: дидактикометодологічний аспект. Науковий вісник Чернівецького університету. Серія.: Педагогіка та психологія: зб. наук. праиь. Чернівці, 2015. Вип. 734. C. 101-109. URL: http://elar.khnu.km.ua/jspui/handle/ 123456789/4049 (дата звернення: 15.03.2019).

8. Рамкова програма 3 німецької мови професійного спілкування для вищих навчальних закладів України / упоряд.: Аззоліні Л.С., Амеліна С.М., Гаманюк В.А., Жданова Н.С. Київ: Ленвіт, 2014. 136 с. 
9. Савченко О.Я. Уміння вчитися як ключова компетентність неперервної освіти: доповідь, 2010. URL: http://dosvidloippo.at.ua/load/pisljadiplomna_osvita/savchenko_o_ja_quot_um (дата звернення: 14.07.2016).

10. Турчин А. Організаційні аспекти удосконалення іншомовної підготовки студентів неспеціальних факультетів. Тернопільський національний педагогічний університет імені В. Гнатюка: Наукові записки, 2017. 1. С. $184-192$.

11. Bialik M. Skills for the 21st Century: What Should Students Learn? Boston, Massachusetts: Centre for Curriculum Redesign, 2015. 19 p.

12. Communication in English for Exchange Students. Single subject course. Linkoeping University: Faculty of science and engineering, 2018. 9 p.

13. Curriculum for the bachelor program Economy of the Enterprise [Curriculum fbr das Bachelorstudium Betriebswirtschaft] (Version 2014). University of Vienna, 2014. 21 p.

14. EF English Proficiency Index: executive summary. Education First. 2018. URL: www.ef.com /ері. (дата звернення: 12.03.2019).

15. Prevedel A. Values and Beliefs: The World View Behind Curriculum. The Annual Review of Adult Learning and Literacy. 2003, 3. P. 8-13.

\section{REFERENCES}

Bialik, M. (2015). Skills for the 21st Century: What Should Students Learn? Boston, Massachusetts: Centre for Curriculum Redesign [in English].

Borisko, N.F. (2006). Novye tipovie program po inostrannym yazykam dlia vuzov i ikh osobennosti [New standard syllabi of foreign languages for universities and their peculiarities]. Inozemni movy [Foreign languages]. Kyiv: KNLU, 6, pp. 3-9 [in Russian].

Communication in English for Exchange Students. Single subject course. (2018). Linkoeping University: Faculty of science and engineering [in English].

Curriculum for the bachelor program Economy of the Enterprise [Curriculum fbr das Bachelorstudium Betriebswirtschaft] (Version 2014). (2014). University of Vienna [in German].

EF English Proficiency Index: executive summary. Education First. (2018). Available: www.ef.com /epi [Accessed March 12, 2019] [in English].

Ismailov, E.E. (2002). Shvedskaya model dovuzovskoy professional'noy podgotovki [The Swedish model of pre-university vocational training]. Karlskrune: municipal gymnasieskola named after Chapmen [in Russian]. 
Lyst Ministerstva osvity i nauky Ukrayiny "Pro orhanizatsiyu vyvchennya humanitarnykh dystsyplin” № 1/9-120 dated March 11, 2015 [The Letter of the Ministry of Education and Science of Ukraine "On the organization of learning the Humanities” №1/9-120 dated March 11, 2015]. (2015). Available at: http://osvita.ua/legislation/Vishya_osvita/46343/ [Accessed February 17, 2019].

Movchan, L.H. (2012). Rozvytok zmistu skil'noii inshomovnoii osvity v Korolivstvi Shvetsia [Development of the content of school foreign language education in the Kingdom of Sweden]: Candidate's Thesis. Kyiv: The Open University of Human Development "Ukraine” [in Ukrainian].

Nakaz MON Ukrayiny "Pro orhanizatsiyu vyvchennya humanitarnykh dystsyplin za vil'nym vyborom studenta” 642 dated July 09, 2009 [The Order of the Ministry of Education and Science of Ukraine "On the organization of free-choice learning the Humanities" 642 dated July 09, 2009]. (2009). Available at: http://old.mon.gov.ua/ua/aboutministry/normative/147 [Accessed February 22, 2019] [in Ukrainian].

Pasichnyk, O.S. and Pasichnyk, O.O. (2015). Optymizatsiya protsesu inshomovnoyi pidhotovky studentiv nemovnykh spetsialnostey: dydaktyko-metodolohichnyy aspect [Optimization of foreign language training of students of nonlinguistic specialties: didactic and methodological aspect]. Naukovyy visnyk Chernivetskoho universytetu, Seria: Pedahohika ta psykholohiya [Scientific Bulletin of Chernivtsi University. Series: Pedagogy and Psychology]. Chernivtsi, 734, pp. 101109. Available at: http://elar.khnu.km.ua/jspui/handle/123456789/4049] [Accessed March 15, 2019] [in Ukrainian].

Prevedel, A. (2003). Values and Beliefs: The World View Behind Curriculum. The Annual Review of Adult Learning and Literacy. 3, pp. 8-13 [in English].

Ramkova prohrama $\mathrm{z}$ nimetskoyi movy profesiynoho spilkuvannya dlya vyshchykh navchal'nykh zakladiv Ukrayiny [Curriculum Framework for the German professional communication in higher educational institutions of Ukraine]. (2014). Azzolini, L.S., Amelina, S.M., Hamanyuk, V.A. and Zhdanova, N.S. (Comps.). Kyiv: Lenvit [in Ukrainian].

Savchenko, O.Ya. (2010). Uminnia vchytysia yak kliuchova kompetentnist' neperervnoii osvity [The Ability ty learn as a key competency of sustainable education]. Available: http://dosvid-loippo. at.ua/load/pisljadiplomna_osvita/savchenko_o_ja_quot_um [Accessed July 14, 2016] [in Ukrainian]. 
Turchyn, A. (2017). Some aspects of advanced foreign language training of students of non-special departments at high schools. Ternopilskyj nacionalnyj pedagogichnyj universytet imeni V. Gnatyuka: Naukovi zapysky [Ternopil Volodymyr Hnatiuk National Pedagogical University: Scientific Notes]. Ternopil, 1, pp. 184-192 [in Ukrainian].

Zahalnoyevropeyski Rekomendatsiyi z movnoyi osvity: vyvchennya, vykladannya, otsinyuvannya [The Common European Framework of Language Portfolio: learning, teaching, evaluation]. (2003). Nikolayev, S.Yu. (Ed.). Kyiv: Lenvit [in Ukrainian].

Стаття надійшла до редакиії: 25.03.2018

Мовчан Лариса Григорівна, канд. пед. наук, доцент кафедри гуманітарних і фундаментальних дисциплін Вінницького навчальнонаукового інституту економіки ТНЕУ (21018, Вінниця, вул. Гонти, 37); e-mail: larisa.movchan.ua@gmail.com; orcid: http://orcid.org/00000003-0913-3240.

Мовчан Лариса Григорьевна, канд. пед. наук, доцент кафедри гуманитарных и фундаментальных дисциплин Винницкого учебнонаучного института экономики ТНЭУ (21018, Винница, ул. Гонты, 37); e-mail: larisa.movchan.ua@gmail.com; orcid: http://orcid.org/00000003-0913-3240.

Larysa Movchan, $\mathrm{PhD}$ in Pedagogics, Associate Professor, Humanities Department, Vinnytsia Educational and Scientific Institute of Economics of Ternopil National Economic University (21018, Vinnytsia, 37, Honty str.); e-mail: larisa.movchan.ua@gmail.com; orcid: http://orcid.org/0000-0003-0913-3240. 